\title{
The Distribution of Dopamine D2 Receptor Heteronuclear RNA (hnRNA) in the Rat Brain
}

\author{
Charles A. Fox, Alfred Mansour, Robert C. Thompson, James R. Bunzow*, Olivier Civelli* \\ and Stanley J. Watson, Jr
}

Mental Health Research Institute, University of Michigan, Ann Arbor, MI 48109-0720, U.S.A

*Vollum Institute for Advanced Biomedical Rescarch. The Oregon Health Sciences University. Portland. OR 97201. USA

\begin{abstract}
Conventional in situ hybridization methods have been useful in characterizing the anatomical distribution of cells in the central nervous system that express dopamine D2 receptor $m$ R NA. However, due to the large size of the D2 mRNA pool, this method may be insensitive to changes in D2 gene transcription. We have developed a method of hybridizing a ${ }^{35} \mathrm{~S}$-labelled $\mathrm{CRNA}$ probe to an intron in the D2 receptor gene in order to measure the amount of primary transcript or heteronuclear RNA (hnRNA) in D2-expressing cells. Introns are found uniquely in hnRNA and are thought to be short-lived intermediates. Thus, monitoring introns could represent a more direct measure of $D 2$ gene transcription. The anatomical distribution of the D2 hnRNA is similar to the distribution of D2 $\mathrm{mRNA}$ in the rat brain. D2 heteronuclear RNA was found in the nuclei of cells in the caudate putamen, nucleus accumbens. hippocampus, olfactory tubercle, substantia nigra, ventral tegmental area. and zona incerta. Other regions that contain D2 mRNA, but do not demonstrate intronic signal, include the globus pallidus, prefrontal, cingulate, entorhinal, and piriform cortex, septum. and amygdala. However, these areas have low amounts of D2 mRNA and may contain levels of D2 hnRNA that are below detection. Heteronuclear RNA quantitation by solution hybridization followed by RNase protection was performed on striatum, substantia nigra, cerebral cortex, hippocampus. hypothalamus, and pit uitary using a D2 intron $7 /$ exon 8 border probe. These results corroborate the distribution of hnR NA revealed with intronic in situ hybridization. In addition, protection assays were able to detect hnRNA in areas that express low levels of D2 like the cortex, hippocampus and hypothalamus. hnRNA mRNA ratios calculated from intron/exon border probe protection assays were not equivalent for all the tissue areas studied, indicating that transcription and or hnRNA half lives may differ between tissues that express D2 receptors. The combined use of intronic in situ hybridization and intron/exon border protection assay as an index of D2 gene transcription and RNA processing provides more information than measuring the mRNA pool alone. It may also prove to be a more useful measure of gene regulation. allowing for evaluation of gene responses to acute treatments.
\end{abstract}

KFY WORDS: Intron In situ hybridization, RNase protection assay

\section{INTRODUCTION}

Molecular cloning techniques have identified five dopamine receptors that can be differentiated based on their nucleotide and amino acid sequences. Pharmacologically, they can be segregated into two families. The D1 family contains the D1 and D5 receptors which have a similar D1-like pharmacology, a small third cytosolic loop, and a long Cterminal domain (Dearry et al., 1990; Monsma 't al., 1990; Sunahara et al., 1990, 1991; Zhou et al., 1990). The D2 family contains the D2, D3 and D4 receptor subtypes. These receptors have a similar

Address correspondence to: Charles A. Fox, Mental Health Research Institute, University of Michigan, 205 Zina Pitcher Place. Ann Arbor. Michigan 48109-0720, USA.
D2-like pharmacology, a large third cytosolic loop, and a short C-terminal domain (Bunzow et al., 1988: Grandy et al.. 1989; Sokoloff e't al., 1990; Van Tol e't al., 1991). Signal transduction also differs between the D1 and D2 family of receptors. The Dl family of dopamine receptors is positively coupled to cAMP production through simulatory $G$-proteins, while receptors in the D2 family are either not coupled or are negatively coupled to cAMP production (Stoof and Kebabian, 1984: Niznik and Van Tol, 1992).

The D1 and D2 mRNAs have a broad anatomical distribution in the rat brain. Both receptor mRNAs are localized in the parallel nigrostriatal and mesolimbic systems. DI mRNA is localized to cells in the striatum and D2 being found in postsynaptic 
striatal cells as well as presynaptic dopamineproducing cells. Both mRNAs are also found in the olfactory tubercle, cerebral cortex, amygdala, hippocampus and hypothalamus (Meador-Woodruff $e t$ al., 1989; Mansour et al., 1990a, 1991; Fremeau et al., 1991; Weiner et al., 1991). In addition to the ventral midbrain dopaminergic neurons, D2 mRNA is uniquely localized in zona incerta, septum and globus pallidus (Weiner et al., 1991). D3, D4 and D5 receptor mRNAs have much more restricted distributions in the brain. D3 receptor mRNA is found in the striatum, mainly in the nucleus accumbens, the olfactory tubercle and the islands of Calleja (Sokoloff et al., 1990; Bouthenet et al., 1991). D4 receptor mRNA is found in roughly equal amounts in the medulla, amygdala, midbrain, frontal cortex and striatum, and in lower amounts in the olfactory tubercle and hippocampus (Van Tolet al., 1991). Finally, D5 receptor $m$ RNA is located in the parafascicular thalamic nucleus, hippocampus and the cerebral cortex (Tiberi et al., 1991; Meador-Woodruff et al., 1992).

Ligands for the D1 and D2 family of receptors have been used to characterize the brain distribution of these receptor proteins (Bouthenet et al., 1987; Charuchinda et al., 1987; Wamsley et al., 1989; Mansour et al., 1990a). These studies indicate that the binding for D1 and D2 ligands is most robust in the basal ganglia. More recently, a D3-specific ligand 7-hydroxyDPAT has been used in binding studies and indicates that D3 binding is most dense in the nucleus accumbens but is also found at lower levels in other regions of the basal ganglia (Levesque et al., 1992). The lack of specific ligands for D4 and D5 has hindered binding studies of these receptor subtypes.

Since receptor proteins are often not located on neuronal cell bodies, but on processes and terminals, in situ hybridization to dopamine receptor mRNAs has proven to be a valuable technique for localizing cell bodies that express specific dopamine receptor subtypes. In situ hybridization was used to show that Dl mRNA is mainly localized to cells in the striatum, whereas D2 mRNA is found in substantia nigra and ventral tegmental area neurons in addition to cells in the striatum (Meador-Woodruff et al., 1989; Mansour et al., 1990a). This distribution suggests both a pre- and postsynaptic localization of the D2 receptor. In fact, unilateral 6-hydroxydopamine lesions of the ventral midbrain dopamine neurons result in a complete ipsilateral loss of D2 mRNA in the substantia nigra and ventral tegmental area, and a compensatory increase in D2 mRNA in the ipsilateral striatum (Mansour et al., 1990b). Other regions of the brain that contain D2 mRNA include the dopaminergic cells of the zona incerta, and the olfactory bulb, as well as cells in the olfactory tubercle, cerebral cortex, septum, amygdala and hippocampus. The neurointermediate lobe of the pituitary also contains cells that express $\mathrm{D} 2$ receptor $\mathrm{m} R \mathrm{NA}$.
The mechanism of regulation of these receptor molecules is not as well understood. Under extreme conditions of dopamine depletion, as occurs in a 6-hydroxydopamine lesion of the ventral midbrain, dopamine D2 receptors increase in number in the striatum (Creese and Snyder, 1979; Marshall, 1985; Creese and $\mathrm{Xu}, 1992$ ). D2 mRNA levels also increase moderately under these conditions (Mansour et al., 1990b; Creese and Xu. 1992). Rats treated with an irreversible D2 antagonist, fluphenazine-N-mustard, that abolishes $90 \%$ of raclopride binding, also show $20 \%$ changes in D2 mRNA in chronically treated rats (Chen et al., 1992).

More controversial are changes that occur in response to drugs that act on dopamine systems. Haloperidol, an antipsychotic and D2 antagonist, increases the number of D2 receptors in the striatum when it is administered chronically (See et al., 1988: Goss et al., 1991; Creese and Xu, 1992). However, these changes require weeks to develop and changes in mRNA are controversial (Van Tol et al., 1990; Bernard et al., 1991; Rogue et al., 1991; Buckland et al., 1992; Creese and Xu, 1992). Given that the changes in D2 mRNA levels that occur in response to dopamine depletion, or long-term D2 antagonism, may be due to either increases D2 gene transcription or an increase in mRNA stability, our goal was to design a method to monitor more directly transcription of the dopamine D2 receptor gene in situ. To accomplish this goal we targeted hetero-nuclear RNA (hnRNA), the precursor form of the D2 mRNA, because it is thought to be short-lived and should provide an alternative index of transcription to measuring D2 mRNA pools.

The D2 receptor gene has been cloned and, unlike the DI family of receptors, contains multiple introns (Bunzow et al., 1988; Grandy et al., 1989: O'Malley et al., 1991). Within the coding region of the D2 gene there are seven introns that range in size from about 1 to $250 \mathrm{~kb}$ (Buck et al., 1992). In order to generate a probe to recognize uniquely the D2 hnRNA, we subcloned a portion of intron 7, the 3'most intron in the coding region of the gene. Since this $2.5 \mathrm{~kb}$ intron is the last to be transcribed, we reasoned that it may be the most rapidly processed intron.

In this study, we report the distribution of the D2 hnRNA by in situ hybridization and solution phase RNase protection assay in the rat brain. In situ hybridization provides excellent anatomical and cellular resolution, while RNase protection assay gives a measure of mRNA-hnRNA ratios. We show evidence that hnRNA for D2 is located in cell nuclei, as opposed to mRNA, which is found mainly in the cytosol. Furthermore, since these techniques allow a more direct measure of transcription and/or RNA processing, we also discuss the implication of finding different levels of hnRNA in D2 receptor-expressing cells. 


\section{MATERIALS AND METHODS}

\section{Tissue preparation (in situ hybridization)}

Adult male Sprague-Dawley rats (nine; Charles River, $250 \mathrm{~g}$ ) were decapitated and the brains were rapidly removed, frozen in liquid isopentane at $-30{ }^{\circ} \mathrm{C}$ for $30 \mathrm{~s}$, and then stored at $-80^{\circ} \mathrm{C}$ until sectioning. At the time of sectioning the frozen brains were warmed to $-20^{\circ} \mathrm{C}$ and mounted to a chuck with OCT mounting medium. Ten micrometer thick sections were cut using a Bright cryostat, six of the brains were sectioned coronally and three were cut horizontally. The sections were thaw mounted onto polylysine-subbed slides and stored at $-80^{\circ} \mathrm{C}$.

\section{In situ hybridization}

Adjacent sections were processed for D2 mRNA in situ hybridization or D2 intronic in situ hybridization. Briefly, the sections were removed from storage at $-80^{\circ} \mathrm{C}$ and fixed for $60 \mathrm{~min}$ in $4 \%$ formaldehyde at $22^{\circ} \mathrm{C}$. The sections were then rinsed three times in $2 \times \mathrm{SSC}(300 \mathrm{~mm}-\mathrm{NaCl}, 30 \mathrm{~mm}-\mathrm{Na}$ citrate, $\mathrm{pH}$ 7.2) and incubated in proteinase $\mathrm{K}$ (PK; $1 \mu \mathrm{g} / \mathrm{ml}$ in $100 \mathrm{~mm}$-Tris, pH $8.0,50 \mathrm{~mm}$ EDTA) for $10 \mathrm{~min}$ at $37 \mathrm{C}$. Following PK treatment. the sections were washed in water and then placed in $0.1 \mathrm{M}$-triethanolamine $(\mathrm{pH} \mathrm{8.0)}$ to which acetic anhydride was added to a concentration of 1:400 and the sections were incubated with stirring at room temperature for $10 \mathrm{~min}$. The sections were then rinsed in $2 \times \mathrm{SSC}$ for $5 \mathrm{~min}$, dehydrated in graded alcohols and air dried.

Two radiolabelled RNA probes were used for in situ hybridization. The cRNA used for hybridization to the dopamine $\mathrm{D} 2$ receptor $\mathrm{mRNA}$ has been described previously (Meador-Woodruff et al., 1989: Mansour et al., 1990a). Briefly, this ${ }^{35} \mathrm{~S}$ labelled cRNA probe was transcribed from a $495 \mathrm{bp}$ Sac I-Bg/II fragment of a rat D2 receptor cDNA (Bunzow et al., 1988). This probe corresponds to a portion of the third cytoplasmic loop and the sixth and seventh transmembrane domains of the D2 receptor. This sequence lies $3^{\prime}$ to the 87 -base alternatively spliced exon, so it does not differentiate between the D2 short- and long-form messages. For intronic in situ hybridization to the D2 receptor hnRNA, a cRNA probe directed against the $3^{\prime}$ region of intron 7 was utilized. The DNA template for this probe was a EcoRI-AvaII fragment subcloned from a rat D2 receptor genomic clone (RGB2, Bunzow et al. 1988). This probe corresponds to the $3^{\prime}$ region of intron 7 which interrupts the portion of the gene that encodes the sixth transmembrane domain.

Sections were hybridized overnight to the cRNA probes diluted in hybridization buffer $(75 \%$ formamide; $10 \%$ dextran sulfate; $3 \times$ SSC, $50 \mathrm{~mm}$ $\mathrm{Na}_{2} \mathrm{PO}_{4}$, pH 7.4: $1 \times$ Denhardt's; $0.1 \mathrm{mg} / \mathrm{ml}$ yeast tRNA: 10 mm-dithiothreitol (DTT)). The probes were diluted in the hybridization buffer to a final concentration of $2 \times 10^{6} \mathrm{dpm} 30 \mu \mathrm{l}$. Thirty microliters of the resulting hybridization solution was placed on two coronal sections or one horizontal section, a coverslip was placed on the slide and they were incubated overnight in a humid chamber at $55 \mathrm{C}$

Following hybridization the slides were rinsed three times in $2 \times \mathrm{SSC}$, then treated with R Nase A $(200 \mu \mathrm{g} / \mathrm{ml}$ in $100 \mathrm{~mm}-\mathrm{Tris}, \mathrm{pH} 8.0$ and $0.5 \mathrm{M}-\mathrm{NaCl}$ ) for $60 \mathrm{~min}$ at $37 \mathrm{C}$. The sections were then rinsed in $2 \times$ SSC followed by room temperature washes in $1 \times \mathrm{SSC}$ for $5 \mathrm{~min}, 0.5 \times \mathrm{SSC}$ for $5 \mathrm{~min} .0 .1 \times \mathrm{SSC}$ for $5 \mathrm{~min}$. Finally the sections were washed in $0.1 \times \mathrm{SSC}$ at $65 \dot{\mathrm{C}}$ for $60 \mathrm{~min}$. rinsed with room temperature water, dehydrated in graded alcohols. air dried, and exposed to Kodak XAR-5X-ray film. The D2 mRNA in situ hybridizations were exposed for 1 day while the D2 intronic in situ hybridizations were exposed for 7 days. Following $X$-ray exposures, the slides were dipped in Kodak, NTB-? emulsion and stored in the dark at $4 \mathrm{C}$ for 30 days for D2 mRNA or 90 days for D2 hnRNA prior to development.

Controls for the D2 $495 \mathrm{mRNA}$ probe halve been described previously (Mcador-Woodruff et al.. 1989: Mansour et al., 1990a). The D2 intronic probe sequence was screened against the Genbank library and was found not to contain any significant identity with sequences other than D2 intron 7 . Methodological controls included sense probe experiments. in which two sets of sections were processed for intronic in situ hybridization. One set was hybridized with the radiolabelled antisense CRNA described above. The other set was hybridized with the complement to this probe or the "sense" probe. Its sequence should be identical to intron 7 and thus should not hybridize. No hybridization signal was observed in sense probe-hybridized sections. R Nase controls were also performed in which one set of sections was treated with R Nase A $(200 \mu \mathrm{g} / \mathrm{ml})$ for $30 \mathrm{~min}$ at $37 \mathrm{C}$ prior to hybridization and another set of adjacent sections was processed normally for intronic in situ hybridization. No hybridization signal was observed on R Nase-pretreated sections.

\section{RNA preparation ( $R$ Nase protection assay)}

Twenty one adult male Sprague Dawley rats (Charles River, $250 \mathrm{~g}$ ) were decapitated and the brains were rapidly removed. The brains were immediately chilled with wet ice and the ventral midbrain, corpus striatum, cerebral cortex, hippocampus, hypothalamus and pituitary were quickly dissected, and frozen on dry ice. Tissue samples were stored at $-80 \mathrm{C}$ until RNA extraction was performed. RNA was extracted from $400 \mathrm{mg}$ of tissue for each brain region using a guanidinium isothiocyanate (GITC) extraction lechnique. Briefly, the tissue was homogenized in a GITC solution (4 M-GITC, 25 mm-sodium citrate. $\mathrm{pH} 7.0 .0 .5 \%$ $\mathrm{N}$-lauryl sarcosine. 0.1 M-2-mercaptoethanol) by 
grinding with a polytron tissue homogenizer. The homogenate was then extracted with phenol, followed by phenol/chloroform and finally chloroform extractions. The RNA was then precipitated from the aqueous phase by incubating at $-20 \mathrm{C}$ with $20 \mu \mathrm{g}$ glycogen, $1 / 40$ th volume $5 \mathrm{M}-\mathrm{NaCl}$, and 3 volumes absolute ethanol for at least $24 \mathrm{~h}$.

\section{Nuclear vs cytosolic RNA preparation}

RNA was also prepared for nuclear versus cytosolic comparison of D2 hnRNA cellular distribution. The procedure for nuclear vs cytosolic RNA extraction has been described by Blum (1989). Striata from rats were dissected as described above. The tissue (one striatum per tube; approximately $40 \mathrm{mg}$ ) was then gently homogenized in $0.3 \mathrm{M}$-sucrose-AT buffer (0.3 M-sucrose; $10 \mathrm{~mm}$-Tris, $\mathrm{pH} 8 ; 3 \mathrm{~mm}-\mathrm{CaCl}_{2}$; $2 \mathrm{mM}-\mathrm{MgCl}_{2} ; \quad 0.5 \mathrm{mM}$ DTT; $0.15 \%$ Triton $\mathrm{X}-$ 100 ) by hand in a $1.5 \mathrm{ml}$ Eppendorf tube with a homogenizing tool that had close tolerance with the tube walls. The homogenate was layered over $400 \mu \mathrm{l}$ of $0.4 \mathrm{M}$-sucrose-AT buffer $(0.4 \mathrm{M}$-sucrose; $10 \mathrm{mM}$ Tris, $\mathrm{pH} 8 ; 3 \mathrm{mM}-\mathrm{CaCl}_{2} ; 2 \mathrm{~mm}-\mathrm{MgCl}_{2} ; 0.5 \mathrm{~mm}-$ DTT; $0.15 \%$ Triton X-100) in a $1.5 \mathrm{ml}$ Eppendorf tube and centrifuged at $2500 \mathrm{~g}$ for $10 \mathrm{~min}$. The resulting supernatant contains cytosolic RNA and was collected, PK $(0.1 \mathrm{mg} / \mathrm{ml})$ treated in SET buffer (10 mm-Tris- $\mathrm{HCl}, \mathrm{pH} 8 ; 5 \mathrm{~mm}$-EDTA; $10 \%$ SDS) at $45^{\circ} \mathrm{C}$ for $1 \mathrm{~h}$. Finally the samples were organically extracted and precipitated overnight at $-20^{\circ} \mathrm{C}$ with $1 / 10$ th volume $5 \mathrm{~m}$-ammonium acetate and 1 volume isopropanol.

The pellets contained the nuclei and resuspended in $0.3 \mathrm{M}$-sucrose-AT buffer and centrifuged through another $0.4 \mathrm{M}$-sucrose-AT cushion. Pellets were then resuspended in $300 \mu \mathrm{l}$ of DNAse I buffer ( $50 \mathrm{~mm}$-Tris- $\mathrm{HCl}, \mathrm{pH} 8 ; 5 \mathrm{~mm}-\mathrm{MgCl}_{2} ; 1 \mathrm{~mm}$-DTT). They were then incubated for $5 \mathrm{~min}$ at $37^{\circ} \mathrm{C}$ with $1 \mu \mathrm{l}$ RNase inhibitor and $2 \mu 1$ RNase-free DNAse I. Following DNAse treatment, $30 \mu \mathrm{l}$ of $10 \times \mathrm{SET}$ buffer was added and the samples were incubated with PK $(0.1 \mathrm{mg} / \mathrm{ml})$ for $1 \mathrm{~h}$ at $45^{\circ} \mathrm{C}$. The resulting sample was organically extracted and precipitated with $1 / 10$ th volume of $5 \mathrm{M}$-ammonium acetate and I volume isopropanol.

\section{RNase protection assay}

For RNase protection assays to the $\mathrm{D} 2$ receptor hnRNA, a ${ }^{32}$ P-labelled cRNA probe complementary to the $3^{\prime}$ end of intron 7 and the 5 end of exon 8 was utilized. The DNA template for this probe as an EcoRI-PstI fragment subcloned from a rat D2 receptor genomic clone (RGB2, Bunzow et al., 1988). This fragment corresponds to the $3^{\prime}$ region of intron 7 and a portion of the sixth and all of the seventh transmembrane domain. The subclone was linearized at an internal $A v a I I$ site and transcribed using T7 RNA polymerase. The resulting cRNA probe includes 374 bases of the $\mathrm{D} 2$ clone that corre- spond to 60 bases of the $3^{\prime}$ end of intron 7 . and 314 bases of exon 8 . Thus, the detection of a $374 \mathrm{bp}$ fragment would indicate the presence of hnRNA. while a 314 bp fragment would correspond to D2 mRNA.

Ten micrograms of total RNA isolated from specific rat brain regions was hybridized to ${ }^{32}$ P-labelled D2 intron 7/exon 8 border probe in $30 \mu \mathrm{l}$ of hybridization buffer $(50 \%$ formamide; 40 mm-PIPES, pH 6.4; $400 \mathrm{~mm}-\mathrm{NaCl} ; 1 \mathrm{~mm}$ EDTA). $100,000 \mathrm{cpm}$ of $\mathrm{cRNA}$ probe was added to each hybridization reaction. The hybridization reactions were then denatured at $90^{\circ} \mathrm{C}$ for $5 \mathrm{~min}$ and then incubated overnight at $65^{\circ} \mathrm{C}$. The following day, the samples were RNase treated by adding $200 \mu \mathrm{l}$ of $10 \mu \mathrm{g} / \mathrm{ml} \mathrm{RNase} \mathrm{A} \mathrm{(in} 10 \mathrm{~mm}$-Tris, $\mathrm{pH} 7.5$; $5 \mathrm{~mm}$-EDTA; $200 \mathrm{~mm}-\mathrm{NaCl} ; 100 \mathrm{~mm}-\mathrm{LiCl})$ and incubating for $30 \mathrm{~min}$ at $37 \mathrm{C}$. The RNase reaction was terminated by adding $10 \mu \mathrm{l}$ of $20 \%$ SDS and $10 \mu \mathrm{l}$ of $10 \mathrm{mg} / \mathrm{ml} \mathrm{PK}$. The PK digestion was incubated for $15 \mathrm{~min}$ at room temperature followed by a 30 -min incubation at $37^{\circ} \mathrm{C}$. The samples were then extracted with phenol/chloroform, followed by chloroform, and were then precipitated overnight at $-20^{\circ} \mathrm{C}$ with $20 \mu \mathrm{g}$ glycogen, $1 / 40 \mathrm{th}$ volume $5 \mathrm{M}$ $\mathrm{NaCl}$, and 3 volumes ethanol. The samples were pelleted and washed with $70 \%$ ethanol, air dried, and rehydrated with $1 \mu \mathrm{l}$ water and $4 \mathrm{ml}$ formamide. The samples were run on a denaturing acrylamide gel $(5 \%$ acrylamide; $50 \%$ urea; $1 \times$ TBE). The gel was then dried and exposed to Kodak XAR-5X-ray film with one intensifying screen at $-80^{\circ} \mathrm{C}$. Exposures of 5-7 days were used in this study.

Controls for the protection assays include running a sample that includes the ${ }^{32} \mathrm{P}$-labelled cRNA probe and no mRNA. Since no hybrids should be formed, no signal is expected in this lane, as was the case in these experiments. Another control procedure involved incubating the radiolabelled RNA probe with yeast RNA. Since D2 RNA is not expected in yeast, no signal is expected in this sample. These lanes were also negative. These controls were run in parallel with samples in each protection assay. In addition, full-length cRNA probe was run on the gels with the protection assays to verify the size of the full-length protected fragments.

\section{Image analysis/RNA quantitation}

Computerized image analysis was used to quantify the amount of specific signal in tissue sections hybridized for D2 hnRNA and $m$ RNA as well as the intensity of the specific bands in RNase protection assays. X-ray exposures of in situ hybridizations were placed on a light table and images were captured using a DAGE-MTI series 68 video camera and a MACINTOSH II microcomputer equipped with an image capture card. A background field (a blank region of the X-ray film) was subtracted from the image to correct for possible inconsistencies in the illumination, and the corrected 
image was analysed. Regions of interest were outlined with a cursor and the average grey level of pixels in this area of interest was calculated by the computer and saved. For direct comparison of the striatum and substantia nigra/VTA, horizontal sections containing both these regions were utilized. Three sections at the level of the dorsal, mid, and ventral substantia nigra were selected. Grey levels were then measured in the striata and substantia nigra VTA of each section.

To quantify bands produced from R Nase proteclion assays, X-ray exposures of protection gels were illuminated on a light table and captured as described for in situ hybridization. For protection assays, regions of interest were specific bands located on these films. The average grey level of specific bands was calculated by the computer and used to formulate hnR NA/mR NA ratio values.

\section{RESULTS}

\section{In situ hybridization}

Heteronuclear RNA transcribed from the dopamine D2 receptor gene was localized by intronic in situ hybridization in all areas of the brain that express moderate to high amounts of D2 mRNA. These regions include the substantia nigra pars compacta (SNC: Fig. 1) and ventral tegmental area (VTA; Fig. 1). zona incerta, caudate-putamen (CPu; Figs 1 and 2). nucleus accumbens (Acb; Figs 1 and 2), hippocampus and olfactory tubercle (Fig. 2.) Other regions that contain $\mathrm{D} 2 \mathrm{mRNA}$, but do not contain D2 intronic signal, include the globus pallidus, prefrontal. cingulate, entorhinal and piriform cortex, septum and amygdala. However, these areas have low amounts of D2 mRNA (Meador-Woodruff et al. 1989) and may contain levels of D2 hnR NA that are below detection. As expected, intronic in situ hybridization also revealed a nuclear localization of this signal in cells, as compared to signal from the D2 mRNA probe, which was localized over the cell nucleus and cy tosol (Fig. 3).

The ratios of D2 hnRNA to D2 mRNA are not equal across all tissues. For example, in the striatum (CPu and Acb combined), a relatively high amount of D2 hnRNA was observed, whereas in the SNC and VTA, low levels of D2 hnRNA were observed (Fig. (B). D2 mRNA, on the contrary, is expressed at very similar levels in the striatum and midbrain (Fig. IA). This observation is substantiated by quantitative data, which indicate that the ratio of striatal signal to SNC/VTA signal is larger for D2 hnRNA than for D2 mRNA (Table 1). In other words. for D2 mRNA in situ hybridization. the amount of signal in the striatum is equal to the amount of signal in the SNC/VTA. However, for D2 hnR NA in situ hybridization, the amount of signal in the striatum is more than twice that observed in the SNCVTA. The differing hnRNA levels in brain regions that express similar levels of D2
mRNA indicate that either gene transcription or hnRNA (and/or mRNA) half lives may vary in these regions even though they possess a similarsized mRNA pool. In order to cross-validate this observation. RNase protection assays designed to measure hnRNA/mRNA ratios were performed.

\section{RNase protection assay}

$\mathrm{RNase}$ protection assays were carried out on dissected regions of the brain including the ventral midbrain (which includes the SNCVTA), striatum. cerebral cortex, hippocampus, hypothalamus and pituitary. On one pool of striata, nuclear versus cytosolic RNA extractions were carried out. R Nase protection assays using the 374-base cRNA probe complementary to intron 7 and exon 8 demonstrate that the full-length protected fragment which represents the intact intron 7 /exon 8 splice site is present only in the nuclear fraction. This indicates that the intron containing D2 RNA is only found in the cell nucleus. A shorter species that runs at the expected size of the exonic portion of the probe $(314$ bases) was found in both nuclear and cy tosolic fractions (Fig. 4). When total cellular RNA from the six brain regions was analysed, border probe protection assays indicated that the distribution of hnRNA agreed with the intronic in situ hybridization data. The ratio of hnRNA to $m$ RNA in the hippocampus was the highest. followed by the striatum. The ventral midbrain had a low hnRNA mR NA ratio (Table 2).

\section{DISCUSSION}

The distribution of dopamine receptor hnR NA by intronic in situ hybridization and RNase protection assay is similar to that reported for D2 mRNA. All regions of the brain that contain moderate to high a mounts of D2 mRNA also have detectable levels of D2 hnRNA. Only regions like the globus pallidus. prefrontal, cingulate, entorhinal and piriform cortex, hippocampus, septum and amygdala, which contain low amounts of D2 mRNA (MeadorWoodruff et al.. 1989), did not have a D2 intronic signal. It seems likely that these regions may simply contain levels of D2 hnRNA that are below detection. In fact. the RNase protection assatys in this study revealed a small amount of $D 2$ hnR NA in the cerebral cortex and a low amount of D2 hnR NA and $\mathrm{mRNA}$ in the hippocampus.

It is not surprising that D2 hnRNA can be detected in cells in brain regions that normally express D2 $m$ RNA and binding (Meador-Woodruff et al. 1989; Mansour et al., 1990a). However. more can be extracted from this data than simply hnR NA distribution. Since intronic in sim hybridization only detects intron-containing RNA species. it is an in vivo measure of D2 RNA molecules that are not included in the mRNA pool. The level of intronic 


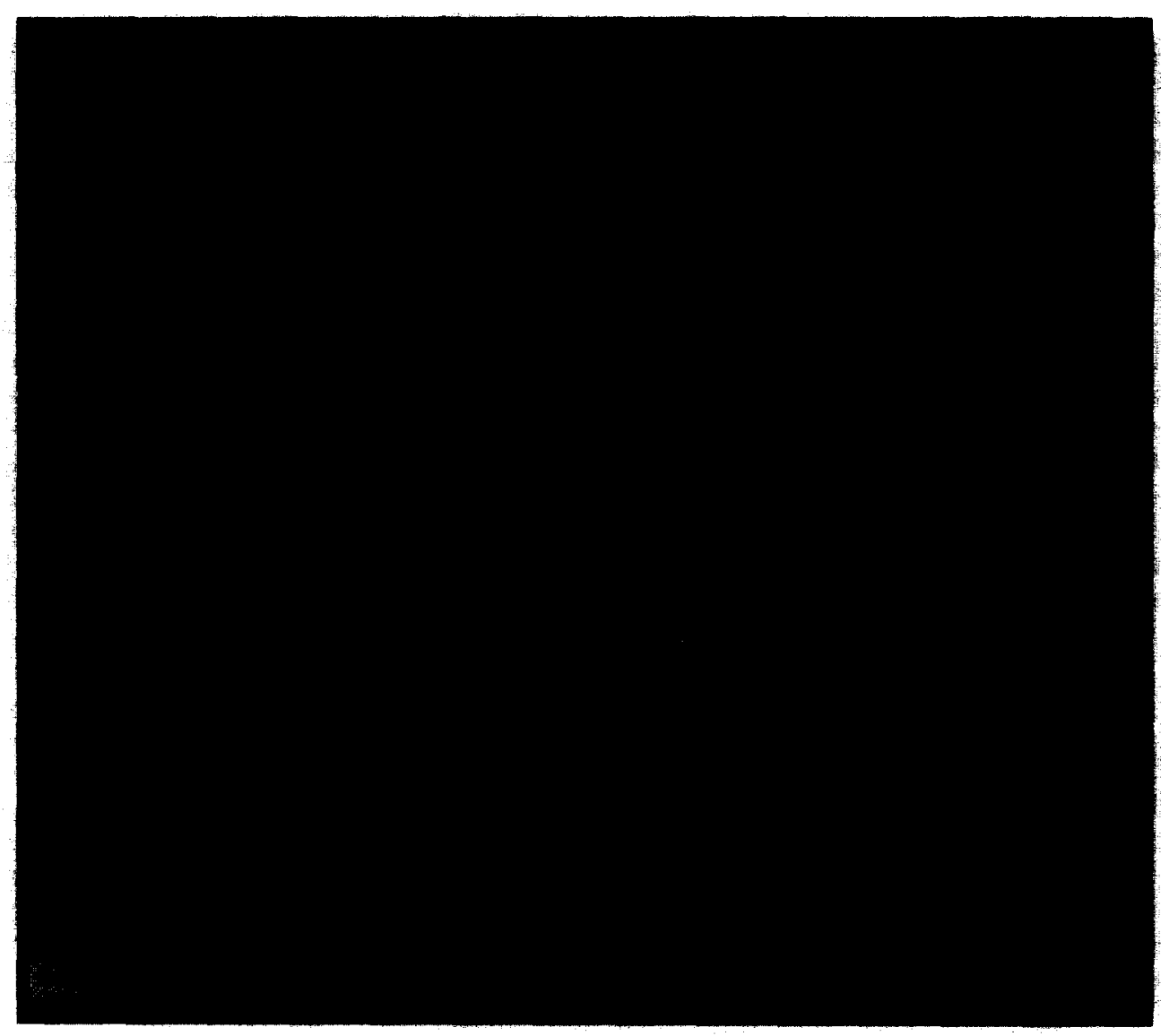

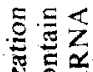

웧

당

s.

政

次

政

尊

递定凂

긍

它

등

政

串

원

을

今.

$\Xi \Xi$

这

है:

중

可

च 0

등

:

논

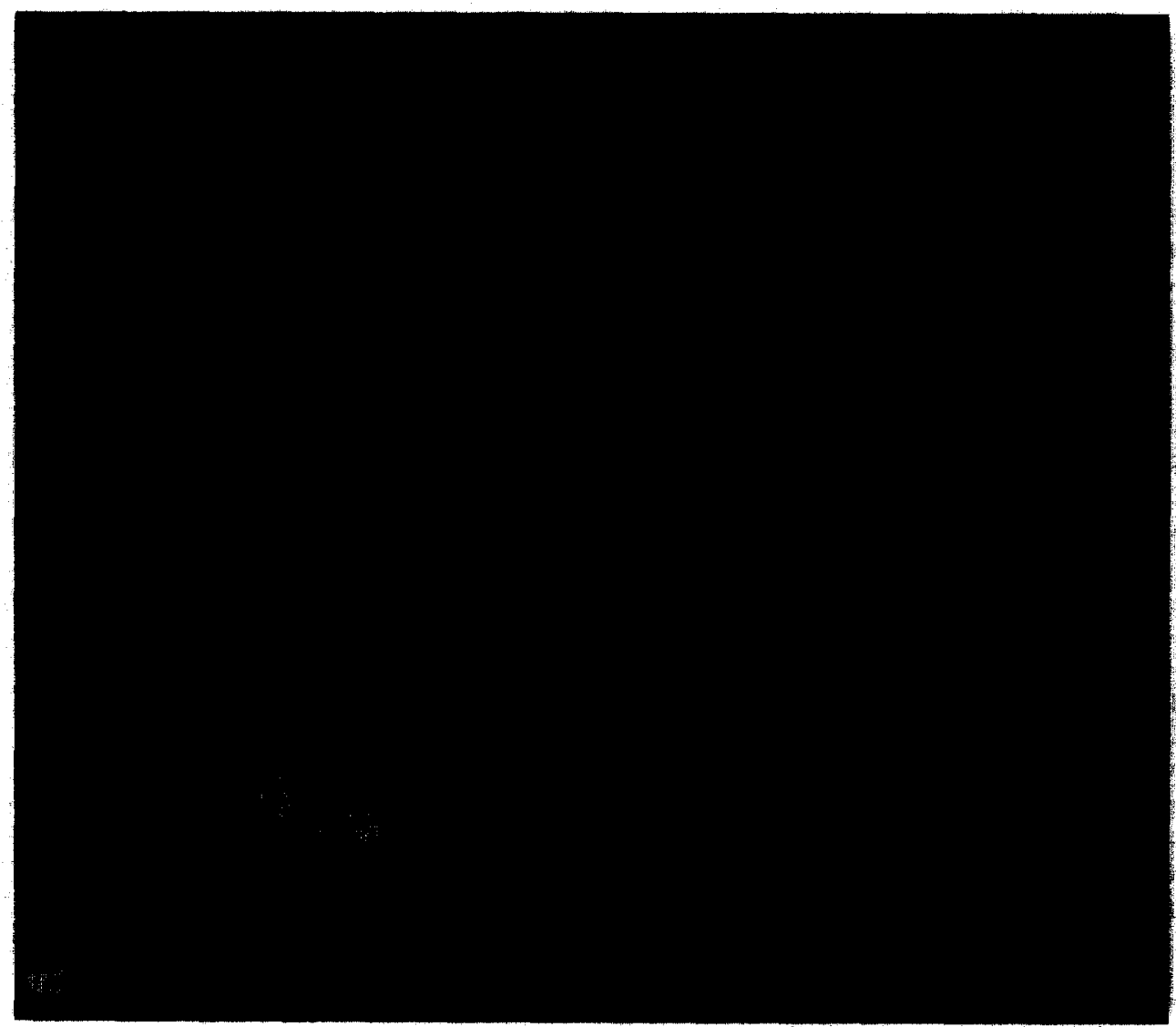

on

可 $n$

등

要

运政

品

둔

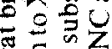

5

을

6t

을

क

중

政

可

政

政

둥

政总

政

응

政

을

들

은 可

政

ธิ

- $\leq$

家家 

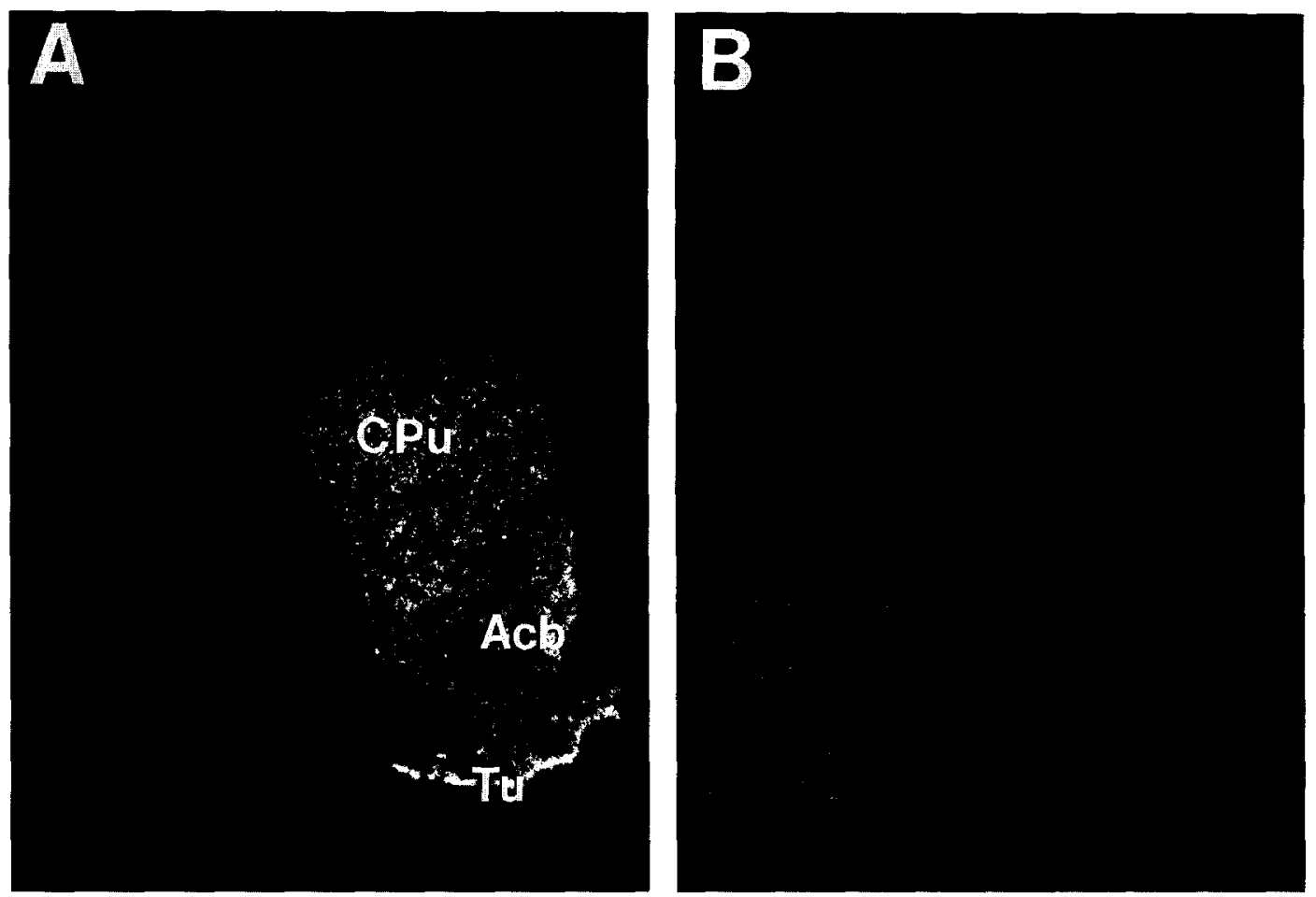

Fig. 2. Dark-field autoradiograms of coronal sections through the rat brain at the lewel of the rostral striatum genterated using dopamine D2 receptor mRNA in situ hybridization (A) and D2 receptor intronic in sim hubridization (B). (A) and (B) represernt 1 - and 7 -dat exposures respectively. Note the correspondence of D2 mRNA and hnRNA in the caludale-putamen (CPul, nucleus atcumbens (Ach). and olfactory tubercle (Tu).

signal is related to $\mathrm{D} 2$ gene transeription as well as D2 hnRNA stability. Thus, regional differences in the level of intronic signal could be due to higher or lower rates of D2 gene transcription and or longer or shorter D2 hnRNA half lives.

For example. D2 mRNA in situ hybridization produces approximately equal amounts of signal in the striatum and the SNC VTA (Fig. IA). However. D2 intronic in simu hybridization produces a much denser signal in the striatum than in the SNCVTA (Fig. IB). RNasc protection data also support this observation. In protection assalys utilizing $D$ ? intron 7 exon 8 border probes, the hnRNA mRNA ratios could be determined for specific brain areas. These ratios were not equal across the brain areas tested. With reference to the mesostriatal system. the striatum has a much higher hnRNA mRNA ratio than the ventral midbrain. When one compares the in situ hybridization regional ratios with the RNase protection assay hnR NA mRNA ratios, data from in situ hybridization indicate that D2 hnR NA signal is $2.3 \times$ denser in the striatum that in the SNC VTA relative to D2 $m$ RNA. Ratios from $R$ Nase protection assay data indicate that the striatum contains $5 \times$ more D2 hnRNA than the ventral midbram relative to D2 $\mathrm{mRNA}$. Considering the differences in these methods. these data are reasonably consistent and clearly support the conclusion that the striatum contains at leatst twice the amount of D2 hnRNA than the SNC VTA. If intronic analysis can be considered an index of RNA synthesis and processing. then it can be interred that D2 RNA may be differentially transcribed and or processed in different brain regions.

Regional differences in D2) gene transcription would not be surprising considering the fact that the D2 gene is being expressed in funclionally diverse cell groups. Data indicate that D2 mRNA in the midbrain mal encode presynaptic or alloreceptors. whereas D2 mRNA in the striatum encodes mainly postsynaptic receptors (Marshall. 1985: Mansour at al. 1990b). No differences in the strueture of the D2 mRNA exist in these wo regions. However. it is interesting to speculate that the rate of R NA synthesis or processing might somehou be related to receptor function.

Otcourse, the differences bherved in D2 hnR NA levels could be a consequence of regional differences in D2 $m R$ R A stability. For example, in the striatum, where high levels of intronic signal are seen. D2 mR $N$ A lurnover may be yuite rapid. Thus, a higher level of tramscription would be required to matintain stealdy-state levels of mRNA. If mR VA turnover is low in the ventral midbrain neurons. one might expect low levels of tanscription. and therefore low levels of intronic signal.

The instability of intron 7 is important to the interpretation of the data presented in this study. The assumption has been made that once spliced oul of the hnRNA introns are rapidly degraded. However. if intron 7 is more stable in the striatum than in the midbrain. one would expeet $b$ see a 


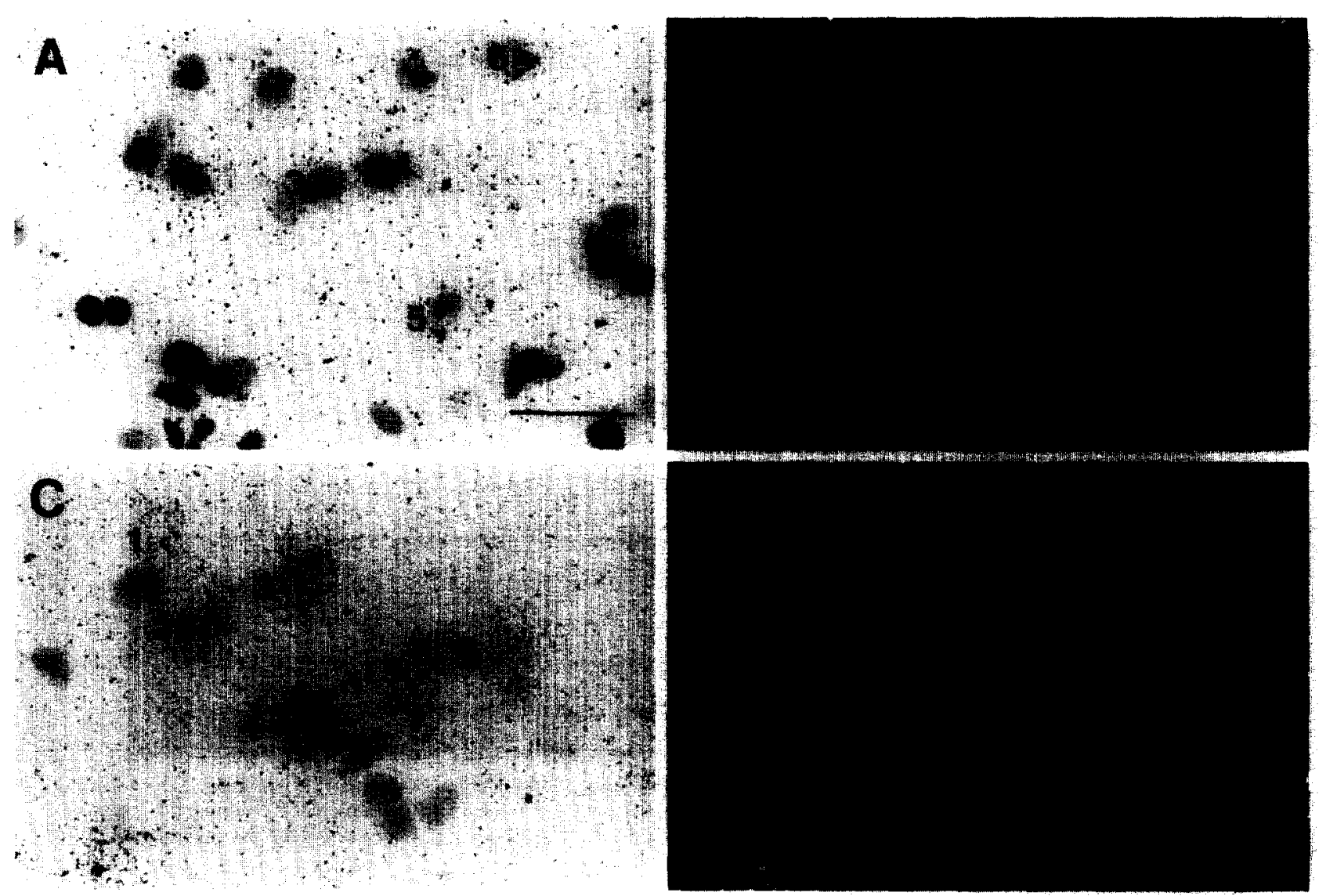

Fig. 3. High-magnification bright-and dark-field photomicrographs of cells in the corpus striatum. In situ hybridization was carried out on rat brain sections using either the $\mathrm{D} 2$ intronic ( 425 base) probe ( $\mathrm{A}$ and $\mathrm{B}$ ) or the $\mathrm{D} 2 \mathrm{mRNA}$ ( 495 base) probe ( $\mathrm{C}$ and $\mathrm{D}$ ). All the sections were counterstained with cresyl violet. Note the nuclear localization of silver grains over cells positive for D2 hnRNA $(1-6)$ A). and the wide dispersion of silver grains over cells positive for D2 mRNA ( $\quad 6 ; C)$. The dark-field photomicrographs clearly show the distribution of silver grains in A (B) and C (D). The black bar in (A) indicates $50 \mu \mathrm{m}$. The magnification is the same in A D

Table 1. Comparison of signal in the striatum and the substantia nigra pars compacta (SNC)/ventral tegmental area (VTA) in in situ hybridizations on horizontal sections for D2 MRNA and D2 hnRNA

\begin{tabular}{|c|c|c|c|}
\hline RNA species & Striatum/SNC.VTA ratio & & \\
\hline D2 mRNA & $1.07 \pm 0.02$ & & \\
\hline D2 hnRNA & $2.43 \pm 0.18$ & $F=55.49$ & $P=0.0017$ \\
\hline
\end{tabular}

higher signal in the striatum. However, if this was true, the border probe RNase protection assays would produce a 60 -base band corresponding to a protected fragment of intron 7 . We have not seen this band in our assays.

There are at least seven introns in the rat dopamine D2 receptor gene. In this study we have utilized intron 7 and its relationship to exon 8 to evaluate D2 hnRNA levels. Since intron 7 is the most $3^{\prime}$ in the coding region of the gene, it is the last intron in the coding region of the gene to be transcribed. Thus, it is likely that this intron has the most fleeting existence. It is possible that there is preferential splicing of certain introns. In fact, intron 5 in the D2 gene is alternatively spliced. When this small 87 - based intron is included in the mRNA it results in the production of the $\mathrm{D} 2 \mathrm{~L}$ receptor which contains a 29 amino acid insert in the third cytosolic loop. It is not known if there is preferential splicing of other introns in the $\mathrm{D} 2$ gene.

It was recently reported that the human D2 gene is approximately $270 \mathrm{~kb}$ in size and includes a $250 \mathrm{~kb}$ intron (Buck et al., 1992). Intron one is the only unusually large intron in this gene. Introns 2-7 range in size from approximately 1 to $3.2 \mathrm{~kb}$ (O'Malley et al., 1990). This unusually large intron located in the coding region of the gene has some interesting implications in the processing of the D2 hnRNA. It is clear that transcription of an intron of this size would occupy a large amount of time and 


\section{C $\mathbf{N}$}

397 -

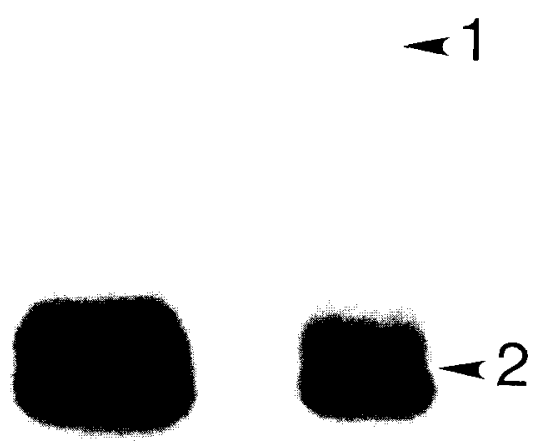

Iig. 4. The wo lanes of this gell represent $R$ Nase protection assays in which an intron exon border probe was hybridized to cylosolic $(C)$ and nuclear (N) RNA preparations. The 397 indicitss the position at which the full-length $\mathrm{c} R$ NA probe (including 23 hases of vector sequence) ran on this gel. The arrow labelled I indicales the position at which a large molecular weight protected fragment ran in this preparation. Its size and unique presence in the nucleal fraction indicates that this hybrid is the product of the 37.4 bases of intron 7 and exon 8 in the CRNA probe and D? hnR NA from the cell nucleus. Note the absence of a high molecuhar weight protected band in the cytosolic RNA preparation. The arrow labelled 2 on this gel indicates the position of a doublet band that runs at the approximate size of the exonic portion of the $\cdot R N A$ probe used in this protection assay. It is present in both nuclear and cytosolic fractions and likely represents processed RNA in the cell nucleus and $m R N A$ in the cytosol. The doublet formation wasconsistently observed in these assays and is likely a product of nicking by the $R N a s e$ at the ends of the probe mRNA hyprid.

Table 2. hnRNA mRNA ratios hased on RNase protection assays on RNA from specific brain regions

R Nitse protection assat

Brain region

hnR NA mR Ratio

Corpus striatum

Ventral midbrain

0.16

Cerebril cortex

Hippocimpus

Hypothatamus

0.032

0.086

0.30

0.014

Pituitary

0.057

cellular energy. Is it possible that the dramatically large size of this intron affects the rate at which is can be cleaved from the sequence?

In addition to monitoring basal hnRNA levels in specific brain regions. the intronic probes may allow a novel view of dopamine D2 receptor gene regulation. Since the hnRNA is the first product of gene transcription and the $\mathrm{D} 2$ receptor has at rather large mRNA pool. this technique may provide a means of detecting subtle regulatory events that have not yet been observed for this receptor gene. The combination of in situ hybridization and $R$ Nase protection assay will be especially powerful in regulatory studies. Protection assay provides a sensitive quantitative measure of change in an RNA species and in situ hybridization allows anatomical resolution to the cellular level. Evaluation of more short-term regulatory events may also be possible with hnRNA analysis.

There are several reports of hnR $\mathrm{RA}$ regulation demonstrated with intronic in situ hybridi/ation. An intron A-specific pro-opiomelanocortin (POMC) probe was utilized to show a rapid increase. then decrease in anterior pituitary cell POMC hnRNA in response to adrenalectomy followed by dexamethasone treatment (Fremeau it al.. 1986). In vivo hnRNA analysis in the brain has revealed rapid increases in corticotropin-releasing hormone in the medial parvicellular paraventricular hypothalamic nucleus in response to acute blockade of glacocorticoid synthesis (Herman of al. 1992), and an increase in the amount of arginine valsopressin (AVP) hnRNA in the supraptic nucleus (SON) aftersalt loading (Herman elal., 1991). Interestingly. the basalAVPhnRNA mRNA ratio was reported to be higher in the suprachiasmatic nucleus that in the SON (Herman ot al.. 1991). All of these reports indicate that regulatory changes in the hnR $N A$ soccurred more rapidly than changes in the corresponding mRNA pook.

In summary, the distribution of D 2 hn RNA by intronic in sim hybridization is similar to the distribution of D2 mRNA. with the exception of areas that express low levels of $D_{2} m R N A$. In these areas it is likely that the levels of $\mathrm{D} 2 \mathrm{~h}$ hRNA are simply below our detection limits. Interestingly, the D2 receptor hnRNA mRNA ratios vary in specific brain regions. For example, the striatum has a high D2 hnRNA mRNA ratio while the ventral midbrain has a lower D2 hnR NA mRNA rittio. This ratio also differs in other regions of the brain. with the hippocampus having a very high $D_{2} 2 \mathrm{hnRN} \Lambda$. mRNA ratio. These quantitative anatomical differences were demonstrated with both intronic in situ hybridization and intron 7 exon 8 horder probe RNase protection assays. These data indicate that discordant rates of D2 gene tanscription. differential D2 hnR NA half lives, or a combination of these two processes contribute to the disparate levels of D2 hnR NA observed in specific hrain regions. We are currently using these tools to understand the regulation of $D 2 m R N A$ production.

\section{ACKNOWLEDGFMENTS}

The authors wish to thank James Stewart for photographic assistance. We also wish to thank (i. W. Kent. (hatrlic Paparian 
and Dave Miller for their indirect, but valuable technical support. This work was supported by NIDA grant DA 02265-12. NIMH grant MH4225l and a Pharmaceutical Manufacturers Association Foundation Award to C.A.F.

\section{REFERENCES}

Bernard, V., Le Moine, C. and Bloch, B. (1991). Striatal neurons express increased level of dopamine $D 2$ receptor mRNA in response to haloperidol treatment: A quantitative in situ hybridization study. Neuroscience 45, $117-126$.

Blum, M. (1989). Regulation of neuroendocrine peptide gene expression. Methods in Enzymology 168, 618-633.

Bouthenet, M. L., Martres, M. P., Sales, N. and Schwartz, J. C. (1987). A detailed mapping of dopamine D2 receptors in rat central nervous system by autoradiography with [ ${ }^{125}$ I]iodosulpride. Neuroscience 120, 117-155.

Bouthenet, M. L., Souil, E., Martres, M. P., Sokoloff, P., Giros, B. and Schwartz, J. C. (1991). Localization of dopamine D3 receptor $\mathrm{mRNA}$ in the rat brain using in situ hybridization histochemistry: Comparison with dopamine D2 receptor D2 receptor mRNA. Brain Res. 564, 203-219.

Buck, K. J., Zhou, Q. Y., Li, C., Grandy, K. D. and Civelli, O. (1992). Organization of the $5^{\prime}$ region of the rat DI and human and rat D2 dopamine receptor genes. Soc. Neurosci. Abstr. 18, 274.

Buckland, P. R., O'Donovan, M. C. and McGuffin, P. (1992). Changes in dopamine D1, D2, and D3 receptor mRNA levels in rat brain following antipsychotic treatment. Psychopharmacology 106, 479-483.

Bunzow, J. R., Van Tol., H. H. M., Grandy, D. K., Albert, P., Salon, J., Christie, M., Machida, C. A., Neve, K. A. and Civelli, O. (1988). Cloning and expression of a rat D2 dopamine receptor cDNA. Nature 336, 783-787.

Charuchinda, C., Supavilai, P., Karobath, M. and Palacios, J. M. (1987). Dopamine D2 receptors in the rat brain: autoradiographic visualization using a high affinity selective agonist ligand. J. Neurosci. 7, $1352-1360$.

Chen. J. F., Oin, Z. H. and Weiss, B. (1992). Irreversible blockade of dopamine receptors by fluphenazine- $\mathrm{N}$ mustard increases D2 dopamine receptor $\mathrm{mRNA}$ and proenkephalin mRNA in rat striatum. Soc. Neurosci. Abstr. 18, 398.

Creese, I. and Snyder, S. H. (1979). Nigrostriatal lesions enhance striatal ${ }^{3} \mathrm{H}$-apomorphine and ${ }^{3} \mathrm{H}$-spiroperidol binding. Eur. J. Pharmacol. 56, 277-281.

Creese, I. and Xu, S. X. (1992). Similarities and differences in dopamine receptor subtype regulation: Molecular mechanisms. Soc. Neurosci. Abstr. 18, 926.

Dearry, A., Gingrich, J. A., Falardeau, P., Fremeau, R. T., Jr, Bates, M. D. and Caron, M. G. (1990). Molecular cloning and expression of the gene for a human D1 dopamine receptor. Nature 347, 72-76.

Fremeau, R. T., Jr, Duncan, G. E., Fornaretto, M.-G., Dearry, A., Gingrich, J. A., Breese, G. R. and Caron, M. G. (1991). Localization of Dl dopamine receptor mRNA in brain supports a role in cognitive, affective, and neuroendocrine aspects of dopaminergic neurotransmission. Proc. Natl. Acad. Sci. USA 88, 3772-3776.

Fremeau, R. T., Jr, Lundblad, J. R., Pritchett, D. B., Wilcox, J. N. and Roberts, J. L. (1986). Regulation of pro-opiomelanocortin gene transcription in individual cell nuclei Science 234, 1265-1269

Goss, J. R., Kelley, A. B., Johnson. S. A. and Morgan, D. G. (1991). Haloperidol treatment increases $D_{2}$ dopamine receptor protein independently of RNA levels in mice. Life Sci. 48, 1015-1022.

Grandy, D. K., Marchionni, M. A., Makam, H., Stotko. R. E., Alfano, M., Frothingham, L., Fischer, J. B., Burke-Howie, K. J., Bunzow, J. R. Server, A. and Civelli, O. (1989). Cloning of the cDNA and gene for a human D2 dopamine receptor. Proc. Natl. Acad Sci. USA 86, 9762-9766.

Herman, J. P., Schäfer, M. K.-H., Thompson, R. C. and Watson, S. J. (1992). Rapid regulation of corticotropinreleasing hormone gene transcription in vivo. Mol. Endocrinol. 6, 1061-1069.

Herman, J. P., Schäfer, M. K.-H., Watson, S. J. and Sherman, T. G. (1991). In situ hybridization analysis of arginine vasopressin gene transcription using intron-specific probes. Mol. Endocrinol. 5, $1447 \ldots 1456$.

Levesque, D., Diaz, J., Pilon, C., Martres, M. P.. Giros, B., Souil, E., Schott, D., Morgat. J. L., Schwartz, J. C. and Sokoloff, P. (1992). Identification, characterization, and localization of the dopamine $\mathrm{D} 3$ receptor in rat brain using 7-[3H]hydroxy-N,N-di-n-propyl-2-aminotetralin. Proc. Natl. Acad. Sci. USA 89, 8155-8159.

Mansour, A., Meador-Woodruff, J. H.. Bunzow, I. R., Civelli. O., Akil, H. and Watson, S. J. (1990a). Localization of dopamine $\mathrm{D} 2$ receptor $\mathrm{m} R \mathrm{NA}$ and $\mathrm{D} 1$ and $D 2$ receptor binding in the rat brain and pituitary: An in situ hybridization-receptor autoradiographic analysis. J. Neurosci. 10, 2587-2600.

Mansour, A., Meador-Woodruff, J. H., Camp, D. M., Robinson, T. E., Bunzow, J., Van Tol. H., Civelli, O., Akil, H. and Watson, S. J. (1990b). The effects of nigrostriatal 6-hydroxydopamine lesions on dopamine D2 receptor mRNA and opioid systems. The International Narcotics Research Conference 89. 227-230.

Mansour, A., Meador-Woodruff, J. H., Zhou, Q. Y., Civelli, O., Akil, H. and Watson, S. J. (1991). A comparison of $D 1$ receptor bindings and $m R N A$ in rat brain using receptor autoradiographic and in situ hybridization techniques. Neuroscience 45, 359--371.

Marshall, J. F. (1985). Neural plasticity and recovery of function after brain injury. In International Review of Neurobiology (eds Smythies, J. R. and Bradley, R. J.), Vol. 26, pp. 201-247.

Meador-Woodruff, J. H., Mansour, A., Bunzow, J. R. Van Tol, H. H. M., Watson. S. J., Jr and Civelli, O. (1989). Distribution of D2 dopamine receptor mRNA in rat brain. Proc. Natl. Acad. Sci. USA 86, 7625-7628.

Meador-Woodruff, J. H., Mansour, A., Grandy, D. K., Damask, S. P., Civelli, O. and Watson, S. J., Jr. (1992). Distribution of D5 dopamine receptor $m R N A$ in rat brain. Neurosci. Lett 145, 209-212.

Monsma, F. J., Mahan, L. C., McVittie, L. D., Gerfen, C. R. and Sibley, D. R. (1990). Molecular cloning and expression of a D1 dopamine receptor linked to adenly] cyclase activiation. Proc. Natl. Acad. Sci. USA 87, $6723-6727$.

Niznik, H. B. and Van Tol, H. H. M. (1992). Dopamine receptor genes: New tools for molecular psychiatry. $J$. Psychiatr. Neurosci. 17, 158-180.

O'Malley, K. L., Mack, K. L., Gandelman, K. Y. and Todd, R. D. (1990). Organization and expression of the rat $\mathrm{D} 2 \mathrm{a}$ receptor gene: Identification of alternative 
transcripts and a variant donor splice site. Biochemistry 29, 1367-1371.

Rogue, P., Hanawer, A.. Zwiller, J., Malviya, A. N. and Vincendon, G. (1991). Up-regulation of dopamine D2 receptor $m$ RNA in rat striatum by chronic neuroleptic treatment. Eur. J. Pharm.-Mol. Pharm. Section 207, 165168 .

See, R. E., Areavagiri, M. and Ellison. G. D. (1988). Chronic neuroleptic treatment in rats produces persisting changes in GABA(A), and dopamine D2, but not dopamine DI receptors. Life Sci 44, 229-236.

Sokoloff, P., Giros. B.. Martres, M. P.. Bouthene1, M. L. and Schwartz, J. C. (1990). Molecular cloning and characterization of a novel dopamine receptor (D3) as a larget for neuroleptics. Nature 347, 146- I5I.

Stoof, J. C. and Kebabian. J. W. (1984). Two dopamine receptors: biochemistry, physiology and pharmacology. Life Sci. 35, 228I-2296.

Sunahara, R. K. Niznik, H. B., Weiner. D. M., Stormann. T. M., Brann, M. R., Kennedy, J. L.. Gelernter, J. E.. Rozmahel, R., Yang. Y.. Isracl, Y.. Seeman. P. and O'Dowd. B. F. (1990). Human dopamine Dl receptor encoded by an intronless gene on chromosome 5 . Vantre 347, 80-83.

Sunahara. R. K.. Guan. H. C.. O'Dowd. B. F., Seeman. P.. laurier, L. G.. Ng. G.. George, S. R.. Torchia. J.. Van Tol.. H. H. M. and Niznik. H. B. (1991). Cloning of the gene for a human dopamine D5 receptor with higher affinity for dopamine than D1. Nature $\mathbf{3 5 0}$. 614619.
Tiberi, M., Jarvie, K. R.. Silva. (C. Falardeau, P.. Gingrich, J. A.. Godinot, N., Bertrand. L.. Yang-Feng. T. L., Fremeau, R. J., Jr and Caron. M. G. (1991). Cloning, molecular characterization, and chromosomal assignment of a gene encoding a second D1 dopamine receptor subtype: differential expression pattern in rat brain compared with the DIA receptor. Pros. Vatl. Acud. Sci. LSA 88, $7491-7495$

Van Tol. H. H. M. Riva. M. Civelli. O. and Crecse. I. (1990). Lack of effect of chronic dopamine receptor blockade on D2 dopamine receptor mRNA level. Neurosci. Lett. 111, 303308.

Van Tol. H. H. M.. Bunzow. J. R.. Guan. H. C.. Sunahara, R. K.. Seeman. P.. Nizmik. H. B. and Civelli. O. (1941). Cloning of the gene for a human dopamine D4 receptor with high affinity for the antipsychotic clozapine. Nature 350, 610-6)14.

Wamsley. J. K.. Gehlert, D. R.. Filloux, F. M. and Dawson. T. M. (1989). Comparison of the distribution of $\mathrm{D} 1$ and $\mathrm{D} 2$ dopamine receptors in the rat brain. $J$. Chem. Veuroumal. 2. $119 \quad 137$

Weiner, D. M.. Levey. A. I.. Sunahara, R. K.. Niznik. H. B. O'Dowd. B. F. Seeman. P. and Brann. M. R. (1991). DI and D2 dopamine receptor $m R N A$ in rat

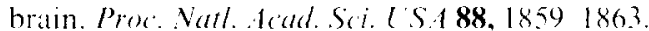

Zhou, Q. Y.. Grandy. D. K.. Thambi. L. Kushner. J. A., Van Tol. H. H. M.. Cone. R., Pribnou. D.. Salon, J., Bunzow. J. R. and (ivelli O. (1990). Cloning and expression of human and rat $D I$ dopamine receptors. Nature $347.76 \quad 80$ 